\title{
Bleach-tolerant Bacterial Species Isolated from Potable Water in Hong Kong
}

\author{
Subramanya Rao ${ }^{1}$, Mui Kwok Wai ${ }^{2}$, Wong Ling Tim ${ }^{2}$ and Leung Polly ${ }^{1 *}$ \\ ${ }^{1}$ Department of Health Technology and Informatics, Hong Kong Polytechnic University, Hung Hom, Kowloon, Hong Kong, China. \\ ${ }^{2}$ Department of Building Services Engineering, Hong Kong Polytechnic University, Hung Hom, Kowloon, Hong Kong, China.
}

Received: January 18, 2017; Accepted: February 05, 2017; Published: February 26, 2017

*Corresponding author: Polly Leung, Department of Health Technology and Informatics, Hong Kong Polytechnic University, Hung Hom, Kowloon, Hong Kong, China. Email: polly.hm.leung@polyu.edu.hk

\begin{abstract}
Sodium hypochlorite $(\mathrm{NaOCl})$ is a common household bleach. The ability of this alkaline salt to kill a wide variety of harmful bacteria upon contact makes it the chemical of choice in treating potable drinking water. Several studies have shown the ineffectiveness of the bleach in killing certain bacteria. We hypothesize that bleach might not be effective to all type of bacteria, especially the one which has the ability to form biofilms. Here we report the isolation and phylogenetic identification of bleach-tolerant bacteria from potable drinking water. The bacterial species isolated from this study phylogenetically affiliated to Ralstonia picketti, usually found in occurrence with biofilm-associated microflora.
\end{abstract}

Keywords: Biofilm; Disinfectant; Sodium hypochlorite; MALDITOF MS; 16S rRNA gene

\section{Introduction}

Water is an essential element for life, contamination of tap water as a result of improper water treatment and disposal serves as a route of the transmission of water-borne diseases. Therefore, provision of safe and clean potable water is one of the most important tasks of the public health sectors.

Chlorine is the chemical of choice in treating potable drinking water due to its effectiveness, high solubility and low cost $[1,2]$. When mixed with water, hypochlorous Acid (HOCl) is formed, which is a strong oxidizing agent that kills bacteria and viruses [3]. It has been documented that exposure to chlorine for about 1 hour achieved a great deal of reduction in the indicator bacterial species in effluent samples [4]. However, this does not necessarily applicable to the entire bacterial population in the water body as the biofilm organisms are resistant to disinfectants [5]. In our experiment, we aimed to test the effectiveness of $\mathrm{NaOCl}$ in killing of potable water microorganisms, especially Legionella, in an artificially constructed potable water distribution system. Furthermore, we also attempted to isolate NaOCl-tolerant bacterial strains. Here we report the isolation and phylogenetic identification of bleach-tolerant bacterial genus Ralstonia from potable drinking water.

\section{Method}

\section{Construction of Model water systems}

A model water distribution system was constructed in order to investigate the ecological relationship between biofilm microorganisms and Legionella in potable water distribution system. Each system comprised an 30-L electric heater, which connected to a potable water circulation system, a makeup water supply system, a duplicate variable speed water pump set (with one pump set served as the standby in case the duty pump was out of order), and control accessories for monitoring temperature, flow rates and other physicochemical properties of water.

In potable water circulation system, the speed pump fed water through the water heater where the water temperature was maintained at $25^{\circ} \mathrm{C}$ and the pump forced the water through the system at sufficient pressure to ensure appropriate circulation flow rate $(0.3 \mathrm{~ms}-1)$.

\section{Introduction of water with microbial consortium into the model systems}

Twenty litres (20L) of water collected from a water tap within a university campus were fed to the model systems. As the water sample was found to be negative for Legionella pneumophila after screening, Legionella pneumophila (ATCC33152) was then inoculated into the system at a concentration of $10^{3}$ colonyforming units (CFU)/ L, this concentration was based on the findings of Legionella counts in potable water system [6]. After feeding of water into the model systems, water was circulated at a flow rate of $1.5 \mathrm{~ms}^{-1}$ for 8 hours in order to distribute the microorganisms within the water systems. After that, water flow rate was maintained at $0.3 \mathrm{~ms}^{-1}$ for 4 weeks.

\section{Disinfection procedures}

Ten 1-ml aliquots of water samples from the model water system were obtained at the end of the $4^{\text {th }}$ week. The samples were placed in $1.5-\mathrm{ml}$ tubes and were then treated with $0 \mathrm{ppm}$, $0.1 \mathrm{ppm}, 0.5 \mathrm{ppm}$ and $50 \mathrm{ppm}$ of bleaching solution for 5, 10 and 30 minutes. One hundred microliters of water sample from each tube were neutralized with $100 \mu \mathrm{l}$ of sodium thiosulphate 
(10\% weight/volume). The neutralized sample was spread on to Buffered Charcoal Yeast Extract (BCYE) agar plates (Oxoid Microbiology products, UK), which is a selective growth media used to isolate gram-negative bacterial species, particularly Legionella pneumophila [7]. These plates were then incubated at $37^{\circ} \mathrm{C}$ in $5 \%$ carbon dioxide for 3 days (2-5 days depended on the growth of bacteria). After incubation, the bacterial colonies were counted. Identities of the bacterial colonies were analyzed using matrix-assisted laser desorption ionization-time of flight mass spectrometry (MALDI-TOF MS). MALDI-TOF MS is a new technology for rapid identification of bacterial species based on protein molecules $[8,9]$. Bacterial identities were further confirmed using PCR amplification and sequencing of the $16 \mathrm{~s}$ rRNA genes as described below.

\section{DNA extraction, PCR, and sequencing}

DNA was extracted from the bacterial isolates using PowerWater culture DNA isolation kit according to the manufacturer's protocol (MO BIO Laboratories Inc., Carlsbad, CA, USA). DNA amplification was performed by PCR. Forward primer 27F (AGAGTTTGATCMTGGCTCAG) and reverse primer 907R (CCGTCAATTCMTTTRAGTTT) were used to amplify the 16s rRNA gene region [10]. The PCR profile included an initial denaturation step at $95^{\circ} \mathrm{C}$ for $10 \mathrm{~min}$, followed by 30 cycles of amplification which consisted of denaturation at $95^{\circ} \mathrm{C}$ for $1 \mathrm{~min}$, primer annealing at $52^{\circ} \mathrm{C}$ for $50 \mathrm{~s}$ and extension at $72^{\circ} \mathrm{C}$ for 1 min. This was followed by a final extension at $72^{\circ} \mathrm{C}$ for $10 \mathrm{~min}$. The presence of PCR products was confirmed by electrophoresis in 1\% agarose gels. Purification of PCR product was carried out using GFX PCR DNA and Gel Band Purification Kit (GE Healthcare, UK). Automated DNA sequencing was performed using dyeterminator cycle sequencing. After cycle sequencing, the purified product was analyzed by capillary electrophoresis on a ABI3730 Genetic Analyzer (Applied Biosystems, US).

\section{Phylogenetic analysis}

The DNA sequences obtained were aligned with reference to the selected GenBank sequences using ClustalW (http://www. genome.jp/tools/clustalw/). Maximum likelihood analysis was conducted using PAUP* 4.0b8 [11]. Phylogenetic trees were drawn using Fig Tree. Bootstrap values $(1,000$ replications) were shown for branch nodes supported by more than $70 \%$. All sequences have been deposited in the NCBI GenBank database under accession numbers (KX025085 - KX025096).

\section{Results and Discussion}

The results revealed that a total of 11 bacterial taxa comprised the Ralstonia taxa. Ralstonia is usually associated with biofilms in water samples. The strains grew on BCYE after treatment with bleach solution at all three concentrations and at different exposure durations. The total bacterial count for the untreated water sample at $\mathrm{T}=0 \mathrm{~min}$ was $3.5 \times 10^{5} / \mathrm{L}$. At $0.1 \mathrm{ppm}$ chlorine concentration, the viable bacterial counts under 5, 10 and 30 min treatment duration were $8.0 \times 10^{4} / \mathrm{L}, 5.4 \times 10^{4} / \mathrm{L}, 4.9 \times 10^{4} / \mathrm{L}$, respectively. For the chlorine concentration at $0.5 \mathrm{ppm}$, the viable bacterial counts under 5, 10 and 30 min treatment duration were
$3.2 \times 10^{4} / \mathrm{L}, 4.1 \mathrm{X} 10^{4} / \mathrm{L}, 7.8 \times 10^{4} / \mathrm{L}$, respectively. For the chlorine concentration at $50 \mathrm{ppm}$, the bacterial counts under 5, 10 and 30 min treatment duration were $4.4 \times 10^{4} / \mathrm{L}, 7.9 \times 10^{4} / \mathrm{L}, 6 \times 10^{4}$ / $\mathrm{L}$, respectively. According to the results, there was less than 10 -fold reduction in bacterial counts under various treatment conditions. Since the bacterial loads were still high even after 50 ppm $\mathrm{NaOCl}$ treatment for $30 \mathrm{~min}$, we investigated the Identities of the bacterial species that were resistant to $\mathrm{NaOCl}$ treatment.

Bacterial isolation using BCYE culture media yielded a total of 11 isolates from 11 samples. These isolates were subjected to MALDI-TOF MS-based identification and further confirmed by $16 \mathrm{~S}$ rRNA PCR and sequencing. Using MALDI-TOF MS, seven isolates were identified as Ralstonia picketti and four bacterial isolates were not identified (Table 1). Using 16S rRNA PCR and sequencing, followed by BLAST search matching against the GenBank database, all 11 bacterial isolates were identified to be Ralstonia picketti or Ralstonia species (Table 1). Phylogenetic analysis revealed that these cultivated isolates resistant to disinfection were Ralstonia picketti isolates (Figure 1).

\begin{tabular}{|c|c|c|c|c|}
\hline \begin{tabular}{|l|} 
Treatment \\
condition \\
(chlorine \\
concentration/ \\
Time of \\
exposure) \\
\end{tabular} & $\begin{array}{l}\text { Bacterial } \\
\text { identity } \\
\text { based on } \\
\text { MALDI- } \\
\text { TOF MS }\end{array}$ & \begin{tabular}{|l|} 
Bacterial identity \\
based on 16S \\
DNA sequencing \\
and BLAST \\
match (Accession \\
number)
\end{tabular} & $\begin{array}{l}\text { BLAST } \\
\text { Identity }\end{array}$ & $\begin{array}{l}\text { Accession } \\
\text { number }\end{array}$ \\
\hline $\begin{array}{l}\mathrm{Nil} / \mathrm{T}=5 \text { or } \\
10 \mathrm{mins}\end{array}$ & $\begin{array}{l}\text { Ralstonia } \\
\text { picketti }\end{array}$ & $\begin{array}{l}\text { Ralstonia picketti } \\
\text { strain CP12 } \\
\text { (KF378754) } \\
\end{array}$ & $99 \%$ & KX025094 \\
\hline $\begin{array}{l}0.1 \mathrm{ppm} / \\
\mathrm{T}=5 \mathrm{mins}\end{array}$ & \begin{tabular}{|l} 
No \\
Organisms \\
Identified
\end{tabular} & $\begin{array}{l}\text { Ralstonia picketti } \\
\text { strain CP12 } \\
\text { (KF378754) }\end{array}$ & $99 \%$ & KX025085 \\
\hline $\begin{array}{l}0.1 \mathrm{ppm} / \\
\mathrm{T}=10 \mathrm{mins}\end{array}$ & $\begin{array}{l}\text { No } \\
\text { Organisms } \\
\text { Identified }\end{array}$ & $\begin{array}{l}\text { Ralstonia picketti } \\
\text { isolate } \text { DiSca } 7\end{array}$ & $96 \%$ & KX025086 \\
\hline $\begin{array}{l}0.1 \mathrm{ppm} / \\
\mathrm{T}=30 \mathrm{mins}\end{array}$ & $\begin{array}{l}\text { Ralstonia } \\
\text { picketti }\end{array}$ & $\begin{array}{l}\text { Ralstonia sp. PH-S1 } \\
\text { (JN543508) }\end{array}$ & $99 \%$ & KX025087 \\
\hline $\begin{array}{l}0.3 \mathrm{ppm} / \\
\mathrm{T}=5 \mathrm{mins}\end{array}$ & $\begin{array}{l}\text { Ralstonia } \\
\text { picketti }\end{array}$ & $\begin{array}{l}\text { Ralstonia picketti } \\
\text { strain CP12 } \\
\text { (KF378754) } \\
\end{array}$ & $98 \%$ & KX025088 \\
\hline $\begin{array}{l}0.3 \mathrm{ppm} / \\
\mathrm{T}=10 \mathrm{mins}\end{array}$ & \begin{tabular}{|l} 
No \\
Organisms \\
Identified
\end{tabular} & $\begin{array}{l}\text { Ralstonia sp. PH-S1 } \\
\text { (JN543508) }\end{array}$ & $99 \%$ & KX025089 \\
\hline $\begin{array}{l}0.3 \mathrm{ppm} / \\
\mathrm{T}=30 \mathrm{mins}\end{array}$ & \begin{tabular}{|l} 
No \\
Organisms \\
Identified
\end{tabular} & $\begin{array}{l}\text { Ralstonia picketti } \\
\text { strain CP12 } \\
\text { (KF378754) }\end{array}$ & $99 \%$ & KX025090 \\
\hline $50 \mathrm{ppm} / \mathrm{T}=5 \mathrm{mins}$ & $\begin{array}{l}\text { Ralstonia } \\
\text { picketti }\end{array}$ & $\begin{array}{l}\text { Ralstonia sp. PH-S1 } \\
\text { (JN543508) }\end{array}$ & $99 \%$ & KX025091 \\
\hline $\begin{array}{l}\text { 50ppm/ } \\
\mathrm{T}=10 \mathrm{mins}\end{array}$ & $\begin{array}{l}\text { Ralstonia } \\
\text { picketti }\end{array}$ & $\begin{array}{l}\text { Uncultured } \\
\text { Ralstonia sp. Clone } \\
\text { M_KL_110_14 } \\
\text { (KP967487) }\end{array}$ & $99 \%$ & KX025092 \\
\hline $\begin{array}{l}\text { 50ppm/ } \\
\mathrm{T}=30 \mathrm{mins}\end{array}$ & $\begin{array}{l}\text { Ralstonia } \\
\text { picketti }\end{array}$ & $\begin{array}{l}\text { Ralstonia picketti } \\
\text { strain CP12 } \\
\text { (KF378754) }\end{array}$ & $99 \%$ & KX025093 \\
\hline
\end{tabular}




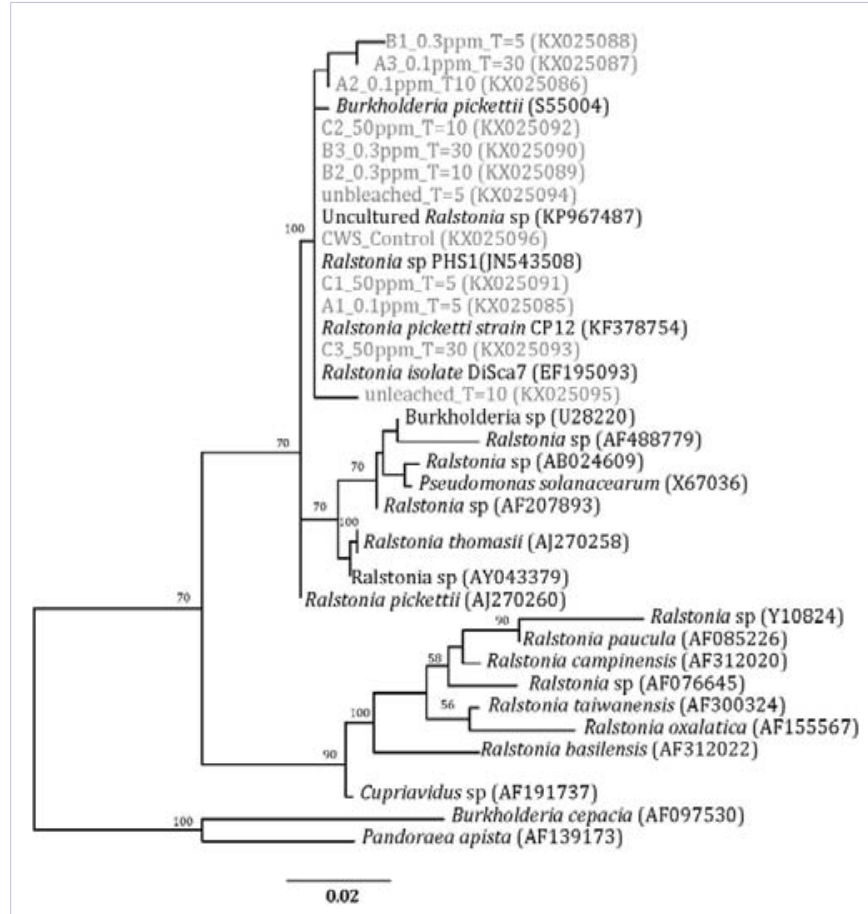

Figure 1: Phylogenetic relationships of cultivated NaClO tolerant strain and related species based on 16s rRNA gene. Tree topologies are supported by bootstrap values for 1,000 replications. Scale bar, 0.02-nt change per position.

Ralstonia picketti is a Gram-negative bacterial species frequently found in water and known for its ability to form biofilms in aquatic environments [12,13]. Our findings showed that the isolates could survive various $\mathrm{NaOCl}$ treatment conditions, even at $50 \mathrm{ppm}$ concentration for 30 minutes. Earlier studies showed that Ralstonia pickettii had the ability not only to survive but also to thrive in oligotrophic conditions $[12,13]$ this might be attributed to its bio-degradative abilities. Furthermore, the ability of Ralstonia picketti to form biofilms [14] may help to resist to biocides and making Ralstonia difficult to be eradicated even with the higher concentration of sodium hypochlorite. Furthermore, Ralstonia pickettii has been also recovered from a wide range of clinical environments and emerged as an opportunistic pathogen [15]. Although the study was designed to isolate Legionella pneumophila strains using Legionella-specific growth medium. In this study, we were not able to recover Legionella strain using culture-based methods in both untreated and treated water samples, the reasons were unknown. However, in our another study, < 1\% Legionella was detected in both untreated and treated potable water samples using high throughput sequencing methods (Unpublished data).

Previous research has successfully demonstrated a 5-log decrease of Legionella species in 5 hours using hyper chlorination [16]. Our study has demonstrated that even after disinfection using $50 \mathrm{ppm} \mathrm{NaOCl}$ for 30 minutes, we were able to isolate Ralstonia picketti. This further reflects the ineffectiveness of bleach in eradicating this bacterial species in potable water. The possible reasons for bleach toleration in Ralstonia could be due to its bio-degradative ability [13] and its ability to form biofilms in potable water [14]. Recent studies demonstrated that microorganisms survive within biofilm can acquire microbial resistance to chemical disinfectants [17]. In summary, our study has isolated a disinfectant-tolerant bacterial species from chlorinated potable water system. It is likely that the oligotrophic environment in water and the ability to utilize a variety of compounds as carbon and nitrogen sources by this organism facilitated its survival and propagation in such environment. A detailed study on the entire bacterial genome would enhance our current knowledge on the genes that associated with high tolerance to $\mathrm{NaOCl}$. Furthermore, it is also important to study the relationship between Ralstonia and Legionella, as Ralstonia form biofilm which favors the survival of Legionella.

\section{References}

1. White, G. "Handbook of chlorination". 3rd ed. New York, Van Nostrand Reinhold. 1992.

2. Charles D. Ericsson, Robert Steffen, Backer H. Water Disinfection for International and Wilderness Travelers. Clin. Infect. Dis. 2002;34:355364. doi: $10.1086 / 324747$

3. Winter J, IIbert M, Graf PC, Ozcelik D, Jakob U. Bleach activates a redox-regulated chaperone by oxidative protein unfolding. Cell. 2008;135(4):691-701. doi: 10.1016/j.cell.2008.09.024

4. Du JR, Li KX, Zhou J, Gan YP, Huang GZ. Sodium hypochlorite disinfection on effluent of MBR in a municipal wastewater treatment process. Huan Jing Ke Xue. 2011;32(8):2292-7.

5. Epstein AK, Pokroy B, Seminara A, Aizenberg J. Bacterial biofilm shows persistent resistance to liquid wetting and gas penetration. Proc Natl Acad Sci U S A. 2011;108(3):995-1000. doi: 10.1073/ pnas.1011033108

6. Cheng VC, Wong SS, Chen JH, Chan JF, To KK, Poon PW, et al. An unprecedented outbreak investigation of nosocomial and communityacquired legionellosis in Hong Kong. Chin Med J. 2012;125(23):428390.

7. Edelstein PH. Improved Semiselective Medium for Isolation of Legionella pneumophila from Contaminated Clinical and Environmental Specimens. J Clin Microbiol. 1981;14(3):298-303.

8. Fenselau C, Demirev PA. Characterization of intact microorganisms by MALDI mass spectrometry. Mass Spectrom Rev. 2001;20(4):157-71.

9. Lay JO. MALDI-TOF mass spectrometry of bacteria. Mass Spectrom Rev. 2001;20(4):172-94.

10.Weisburg WG, Barns SM, Pelletier DA, Lane DJ. 16S ribosomal DNA amplification for phylogenetic study. J Bacteriol. 1991;173(2):697703.

11. Swofford DL. PAUP* Phylogenetic Analysis Using Parsimony (*and Other Methods) Version 4. 2003.

12. Kulakov LA, McAlister MB, Ogden KL, Larkin MJ, O’Hanlon JF. Analysis of bacteria contaminating ultrapure water in industrial systems. Appl Environ Microbiol. 2002;68(4):1548-55.

13. Ryan MP, Pembroke JT, Adley CC. Ralstonia pickettii in environmental biotechnology: potential and applications. J Appl Microbiol. 2007;103(4):754-64. 
14. Anderson RL, Holland BW, Carr JK, Bond WW, Favero MS. Effect of disinfectants on Pseudomonas colonized on the interior surface of PVC pipes. Am J Public Health. 1990;80(1):17-21.

15. Ryan MP, Pembroke JT, Adley CC. Ralstonia pickettii: a persistent gram-negative nosocomial infectious organism. J Hosp Infect. 2006;62(3):278-84.
16. Muraca PW, Yu VL, Goetz A. Disinfection of water distribution systems for Legionella: a review of application procedures and methodologies. Infect Control Hosp Epidemiol. 1990;11(2):79-88.

17. Bridier A, Briandet R, Thomas V, Dubois-Brissonnet F. Resistance of bacterial biofilms to disinfectants: a review. Biofouling. 2011;27(9):1017-32. doi: 10.1080/08927014.2011.626899 